\title{
NON-FORMAL PHYSICAL EDUCATION OF CHILDREN: INCREASE FACTOR OF PHYSICAL ACTIVITY AND PHYSICAL FITNESS
}

\author{
Asta Šarkauskienė, Sigita Derkintienè, Šarūnas Paplauskas \\ Klaipèda University, Klaipéda, Lithuania
}

\begin{abstract}
Background. Studies on physical activity, which is positively associated with physical fitness, reveal that children's activity is not sufficient (BHFNC, 2010; Chen, Zheng, Yi, \& Yao, 2014; Currie et al., 2012), and their physical fitness deteriorates (Volbekienè \& Kavaliauskas, 2002; Мирошниченко \& Астраханцев, 2005; Синявский, Власов, \& Сергеев, 2009). Non-formal physical education (NFPE) is one of the means to increase children's physical activity and physical fitness. The aim of this study was to determine the influence of NFPE on the physical fitness of 6th grade pupils.

Methods. The research was conducted in May, 2013; 356 six-graders ( $48.0 \%$ of girls) from four Klaipeda city comprehensive schools participated in the research. As many as $56.5 \%$ of children ( $48.3 \%$ of girls) participated in NFPE in school and out of school. The participants completed five physical fitness tests.

Results. Independent $t$ test revealed that the results of boys who attended the NFPE group of cardiorespiratory fitness, $t(180)=-2.093, p=.038$; upper body muscular strength and endurance, $t(182)=2.413, p=.017$; abdominal muscular strength and endurance, $t(186)=3.282, p=.001$; explosive leg power, $t(183)=1.967, p=.049$, and girls' results of abdominal muscular strength and endurance, $t(172)=2.687, p=.008$ were significantly higher than those in the NFPE non attended group.

Conclusion. Non-formal physical education is a meaningful educational form for increasing children's, particularly boys', health related physical fitness; therefore it is purposeful to encourage children to participate in physical activities in school and after classes.
\end{abstract}

Keywords: non-formal physical education, physical fitness, testing.

\section{INTRODUCTION}

$\mathrm{P}$ hysical activity is important to the overall health and well-being of everyone, including all school-age children. The benefits of physical activity are well-documented and involve the mitigation of many health risks, including those for developing Type 2 diabetes (Costanian, Bennett, Hwalla, Assaad, \& Sibai, 2014; Rottensteiner et al., 2014), high blood pressure and high blood cholesterol (Carpio-Rivera, Moncada-Jiménez, Salazar-Rojas, \& Solera-Herrera, 2016; Heshmat et al., 2016). Physical activity also contributes to the building and maintenance of healthy bones and muscles (Sioen et al., 2015), to improve positive mental health (Hilmn, Erikon, \& Kramer, 2008; Nguyen - Michel, Unger, Hamilton, \& SpruijtMetz, 2006; Wang et al., 2010), and health-related physical fitness (HRPF) (De Baere, Philippaert, De Martelaer, \& Lefevre, 2016; Malacko \& Pejčić, 2009).

HRPF components are cardiorespiratory fitness, muscular strength and endurance, flexibility and body composition (Gallahue \& Ozmun, 2006; Volbekienè \& Kavaliauskas, 2007). One of the most important components is cardiorespiratory fitness. Its training improves cardiac function and peripheral blood flow and enhances the capacity 
of the muscle fibres to generate greater amounts of adenosine triphosphate (Kenney, Wilmore, \& Cosill, 2012; Skernevičius, Milašius, Raslanas, \& Dadelienè, 2011). Minimal levels of muscular fitness are needed to perform activities of daily living, to maintain functional independence as one age, and to partake in active leisure-time pursuits without undue stress or fatigue (Heyward, 2010).

Empirical research estimated that sixth graders' (12-13-year-old children) daily physical activity is not sufficient (BHFNC, 2010; Chen et al., 2014; Currie et al., 2012; Schneider, Dunn, \& Cooper, 2009) and their physical fitness diminishes (Volbekienè, \& Kavaliauskas, 2002; Мирошниченко \& Астраханцев, 2005; Синявский et al., 2009).

Lessons of physical education are the primary form of the activity children receive at school, but only several countries require daily physical education. Further, physical education programs provide only up to $8-11 \%$ of children's daily physical activity. One of the strategies to increase activity is to promote it within the non-formal physical education (Beets, Beighle, \& Erwin, 2009). California Department of Education (2009) and Carrel et al. (2011) denote that these activities may be the only place where children can regularly engage in physical activity and to seek to increase their physical fitness.

In different countries different words are used to describe more or less the same activities: extracurricular education, after school education, or extra school education. In this study we will use the term of non-formal physical education (NFPE).

The effectiveness of NFPE usually is measured by analyzing NFPE impact on physical activity (Gortmaker et al., 2012; Lubans \& Morgan, 2008), while some literature sources focused on the influence of NFPE on 13-year-old children's health-related physical fitness.

Research by data Carrel et al. (2011), Da Silva, Fisberg, de Sousa Pires, Nassar, and Sottovia (2013) demonstrate that NFPE curriculum in school can improve body composition. Drake et al. (2012) conducted telephone surveys with 1718 high school students and their parents. The scientists estimated that team sport participation had the strongest and most consistent inverse association with weight status. Ara et al. (2006) analysed the effect of NFPE on physical fitness during growth in early pubertal males and found that children who attended NFPE and were physically active at least $3 \mathrm{~h}$ per week during 3 years maintained their physical fitness during growth, while it deteriorated in physically inactive children.

Hypothesis: most of six-graders do not participate in NFPE and HRPF is insufficient. Children who participate in NFPE at least once a week have higher indices of HRPF than those who do not participate in NFPE.

The aim of this study was to determine the influence of NFPE on the physical fitness of 6th grade pupils.

\section{METHODS}

Participants. Research participants were 356 six-graders $(48.0 \%$ girls) from four Klaipeda city comprehensive schools; $56.5 \%$ of children $(48.3 \%$ girls) participated in NFPE at least once a week. Duration of each training session was 1-2 hours. In this research NFPE was defined as a purposeful physical education, organized in school or out of school after the regular school day.

Statistically significantly more boys participated in sports than girls $t(370)=3.062, p=.002$. The duration of attendance was $2.89(S D=2.29)$ years. With regard to gender the attendance duration did not differ significantly, $t(370)=-1.582, p=.114$. The average age of the participants was 13.00 $(S D=0.26)$ years.

Methods. The research was conducted in May, 2013. All physical fitness tests as well as height and weight measurements participants were taken during physical education lessons (one test/ measurement per one lesson).

Consistent with recommendations (Volbekienè \& Kavaliauskas, 2002; Heyward, 2010) healthrelated physical fitness components, which are body composition, flexibility, muscular strength and endurance, and cardiorespiratory fitness, of all study participants were assessed by the physical fitness tests described below.

Height was measured using roller height meter (Seca, Model 206, Germany). The height meter was mounted on the wall and the participants stood erect, barefooted, and looked straight ahead. Before being measured or weighed, pupils were asked to remove their shoes and outer clothing, such as jackets. Height was measured to the nearest half centimetre. Weight was measured to the nearest 0.1 kilogram using a calibrated scale (Seca, Model 709, Germany) that was zero balanced before each pupil was weighed. Body mass index of the participants 


\begin{tabular}{|c|c|c|c|c|c|c|}
\hline \multirow{10}{*}{$\begin{array}{l}\text { Table 1. Distribution } \\
\text { of sixth grade pupils' } \\
\text { participation and } \\
\text { non-participation in } \\
\text { NFPE }\end{array}$} & \multirow{2}{*}{\multicolumn{3}{|c|}{$\begin{array}{c}\text { The distribution of participants } \\
\text { Non-attending NFPE }\end{array}$}} & Girls (\%) & Boys (\%) & Total (\%) \\
\hline & & & & 51.7 & 36.3 & 43.7 \\
\hline & \multicolumn{3}{|c|}{ In school } & 19.7 & 19.7 & 19.7 \\
\hline & \multirow{7}{*}{$\begin{array}{l}\text { Attending } \\
\text { NFPE }\end{array}$} & \multirow{7}{*}{ Out of school } & Totally & 28.8 & 44.0 & 36.6 \\
\hline & & & Dance & 12.4 & 1.6 & 6.7 \\
\hline & & & Swimming & 3.9 & 7.8 & 5.9 \\
\hline & & & Football & 0.6 & 8.8 & 4.9 \\
\hline & & & Dual sports & 1.1 & 8.3 & 4.9 \\
\hline & & & Basketball & 1.1 & 7.8 & 4.6 \\
\hline & & & Other & 9.7 & 9.7 & 9.6 \\
\hline
\end{tabular}

was calculated from their respective height and weight using the relation $=$ weight $/$ height $^{2}$.

Sit and reach (lower back flexibility). The sit and reach was scored at the most distant point (in $\mathrm{cm}$ ) of reaching on a ruler with the fingertips. A sit and reach box was a specially constructed box with the measuring scale where $23 \mathrm{~cm}$ was at the level of the feet. Each participant was given two trials and the best result was chosen. The pupil removed his/ her shoes before sitting at the test apparatus with the knees fully extended.

Sit ups in 30 seconds (abdominal muscle strength and endurance). The sit ups test was scored as the number of sit-ups performed within a $30 \mathrm{~s}$ period. The adolescent lay down on a mat with knees bent at right angles and hands behind the head. The ankles were firmly held by a partner for support and maintaining the count. The pupil's elbows touched the knees during the execution of the test.

Flexed-arm hang (upper body strength and endurance). Flexed-arm hang was scored as the total time is seconds. The participant climbed the ladder to a height so that the chin was at the level with the bar. They grasped the overhead bar using an overhand grip (palms facing away from body), with the hands at shoulder width apart. On the command, "ready, go" the pupil removed their feet from the ladder, and timing started. The pupil had to attempt to hold this position as long as possible. Timing was stopped when the pupil's chin fell below the level of the bar or the head tilted backward to enable the chin to stay at the level with the bar.

Standing long jump (explosive leg power). Standing long jump was scored as the longest distance jump in centimetres. The participant stood behind a line marked on the ground with feet slightly apart. A two foot take-off and landing was used, with swinging of the arms and bending of the knees to provide forward drive. The pupil attempted to jump as far as possible, landing on both feet without falling backwards. Two attempts were allowed.

One mile walk/run (cardiorespiratory fitness). One mile walk/run was measured in minutes. The participants were instructed to try to keep a steady speed and finish running as fast as possible. Walking was permitted when the pupil could not continue running.

Data analysis. Descriptive statistics were calculated (including means $(M)$ and standard deviation $(S D)$ ) for each physical fitness component. One-Sample $T$ test was used to examine the mean difference between the sample and the known value of the population mean. Independent $t$ test was used to examine test differences between two independent (NFPE attended and non-attended) groups. For all the tests, statistical significance was set at $p<.05$. All statistical analyses were performed with the Statistical Package for Social Sciences (SPSS) (version 20.0 for Windows).

Research ethics. All the participants of the research were introduced to research aim and the agreements of them and their parents/guardians were received.

\section{RESULTS}

Descriptive statistics were used to describe the basic features ((the means $(M)$ and standard deviation $(S D)$ ) of the data in a study. Table 2 presents HRPF results of NFPE attending and nonattending groups, and Lithuanian sixth graders' HRPF results.

One - Sample $T$ test shows that indices of the explosive leg power, $t(81)=0.661, p=.510$ and abdominal muscular strength and endurance, $t(84)=0.230, p=.819$ among girls, attending NFPE, and of Lithuanian sixth grade girls did 
Table 2. Health-related physical fitness (HRPF) results (mean, standard deviation)

\begin{tabular}{|c|c|c|c|c|c|c|c|c|c|c|}
\hline \multirow{3}{*}{$\begin{array}{l}\text { Components of } \\
\text { health-related } \\
\text { physical fitness }\end{array}$} & \multicolumn{4}{|c|}{ Girls } & \multirow{3}{*}{$\begin{array}{c}\text { The } \\
\text { results of } \\
\text { Lithuanian } \\
\text { girls' HRPF } \\
\text { (2002) } \\
M\end{array}$} & \multicolumn{4}{|c|}{ Boys } & \multirow{3}{*}{$\begin{array}{c}\text { The } \\
\text { results of } \\
\text { Lithuanian } \\
\text { boys' HRPF } \\
\text { (2002) } \\
M\end{array}$} \\
\hline & \multicolumn{2}{|c|}{$\begin{array}{l}\text { NFPE attending } \\
\text { group } \\
(n=82)\end{array}$} & \multicolumn{2}{|c|}{$\begin{array}{l}\text { NFPE non- } \\
\text { attending group } \\
\quad(n=86)\end{array}$} & & \multicolumn{2}{|c|}{$\begin{array}{c}\text { NFPE attending } \\
\text { group } \\
(n=120)\end{array}$} & \multicolumn{2}{|c|}{$\begin{array}{l}\text { NFPE non- } \\
\text { attending group } \\
(n=68)\end{array}$} & \\
\hline & $M$ & $S D$ & $M$ & $S D$ & & $M$ & $S D$ & $M$ & $S D$ & \\
\hline $\begin{array}{l}\text { Cardiorespiratory } \\
\text { fitness } \\
(1 \text { mile walk/run }(s))\end{array}$ & 651.8 & 79.2 & 659.2 & 79.4 & - & $579.0^{\mathrm{ac}}$ & 110.4 & 614.4 & 108.7 & - \\
\hline $\begin{array}{l}\text { Upper body strength } \\
\text { and endurance } \\
\text { (Flexed-arm } \\
\text { hang(s)) }\end{array}$ & 8.18 & 8.49 & 8.49 & 9.87 & $11.5^{a b}$ & $15.85^{\mathrm{c}}$ & 13.68 & 11.3 & 9.64 & $19.6^{a b}$ \\
\hline $\begin{array}{l}\text { Abdominal muscle } \\
\text { strength and } \\
\text { endurance } \\
\text { (Sit ups in } 30 \\
\text { seconds }(\mathrm{n} / 30 \mathrm{~s})\end{array}$ & $23.31^{\mathrm{c}}$ & 4.25 & 21.72 & 3.52 & $23.20^{b}$ & $26.05^{\mathrm{c}}$ & 4.47 & 23.65 & 5.39 & $25.54^{b}$ \\
\hline $\begin{array}{l}\text { Explosive leg power } \\
\text { Standing long } \\
\text { jump }(\mathrm{cm}))\end{array}$ & 156.37 & 26.73 & 152.16 & 21.86 & 154.41 & $175.57^{\mathrm{c}}$ & 24.26 & 168.15 & 25.15 & 171.86 \\
\hline $\begin{array}{l}\text { Lower back } \\
\text { flexibility } \\
(\text { Sit and reach }(\mathrm{cm}))\end{array}$ & $22.91^{\mathrm{a}}$ & 6.81 & $22.40^{\mathrm{b}}$ & 7.20 & 20.69 & 17.77 & 6.30 & 17.06 & 6.45 & 17.34 \\
\hline BMI $\left(\mathrm{kg} / \mathrm{m}^{2}\right)$ & 19.70 & 3.09 & 19.49 & 3.74 & 18.7 & $19.14^{\mathrm{a}}$ & 3.18 & $19.79^{b}$ & 3.59 & 18.1 \\
\hline
\end{tabular}

Notes. $M=$ mean; $S D=$ standard deviation; NFPE - non-formal physical education.

a - Significant differences between NFPE attending group and Lithuanian sixth grade pupils.

b - Significant differences between NFPE non-attending group and Lithuanian sixth grade pupils.

c - Significant differences between NFPE attending and non-attending groups.

not differ significantly. However, statistically significant differences were found for other HRPF components: results of upper body muscular strength and endurance, $t(79)=-3.505, p=.001$ were lower and results of flexibility, $t(81)=2.950$, $p=.004$ and BMI, $t(79)=2.888, p=.005$ were higher comparing girls attending NFPE with the Lithuanian sixth grade girls.

There were no significant differences in explosive leg power, $t(88)=-0.972, p=.334$, and BMI, $t(85)=0.054, p=.789$, in girls nonattending NFPE group compared to the Lithuanian sixth grade girls. Results of upper body muscular strength and endurance, $t(86)=-2.851, p=.005$, and abdominal muscular strength and endurance, $t(88)=-3.970, p=.000$, were worse and flexibility, $t(86)=2.934, p=.004$, was better in girls nonattending NFPE, group.

No significant differences were found for the abdominal muscular strength and endurance, $t(119)=1.249, p=.214$; explosive leg power, $t(118)=$ $1.669, p=.098$; flexibility, $t(116)=0.737, p=.462$ among boys attending NFPE and of Lithuanian sixth grade boys. Results of upper body muscular strength and endurance, $t(115)=-2.952, p=.004$, were lower and BMI, $t(122)=3.606, p=.000$ was higher in NFPE attending group compared to Lithuanian sixth grade boys.

There were no significant differences in explosive leg power, $t(67)=-0.360, p=.720$; flexibility, $t(67)=-0.360, p=.720$, in boys nonattending NFPE compared to the Lithuanian sixth grade boys. Results of upper body muscular strength and endurance, $t(67)=-7.097, p=.000$; abdominal muscular strength and endurance, $t(67)=-2.897$, $p=.005$, were lower and BMI, $t(66)=3.856, p=$ .000 , was higher in boys non-attending NFPE.

The results of the independent $t$ test indicated that there was a statistically significant difference in abdominal muscular strength and endurance between NFPE attending and non-attending girls, $t(172)=2.687, p=.008$. There was no significant difference between these groups in other HRPF tests, $p>.05$.

Boys' results in the NFPE attending group of cardiorespiratory fitness, $t(180)=-2.093, p=.038$; upper body muscular strength and endurance, $t(182)=2.413, p=.017$; abdominal muscular 
strength and endurance, $t(186)=3.282, p=.001$; explosive leg power, $t(183)=1.967, p=.049$, were significantly higher than in the NFPE non-attending group. Only indices of flexibility, $t(183)=0.734$, $p=.464$ did not differ significantly. There was no significant difference between NFPE attending and non - attending groups in the BMI, $t(188)=-1.294$, $p=.197$.

\section{DISCUSSION}

This study examined the HRPF of sixth grade pupils and the impact of a NFPE on it. NFPE is deliberately chosen by children, planned and purposeful after-school physical education. It was hypothesized that most six-graders did not participate in NFPE and their HRPF was insufficient. Children who participate in NFPE at least once a week have higher indices of HRPF than those who do not participate.

The studies have found that children can obtain up to $50 \%$ of their daily recommended physical activity only in the after-school period (Olds et al., 2008; Tudor-Locke, Lee, Morgan, Beighle, \& Pangazi, 2006). However, a lot of pupils do not participate in NFPE.

According to the study by the Sports Council for Wales (2009), 47\% of secondary school age pupils take part in NFPE regularly (at least once a week). Football (47\%) remains the most popular club activity for boys by a considerable margin, followed by rugby (32\%). Dance and swimming are the most popular activities for secondary school girls. The comparable data were gained by Kromerova and Sukys (2013). The scientists revealed that among research participants, $43.4 \%$ $(n=167)$ were involved in competitive sports. In our study about half (56.3\%) of children participated in NFPE. As in the research of the Sport Council of Wales (2009), most of the boys attended football, while girls attended dance classes.

Studies have suggested that children's HRPF is insufficient and decreasing. Depending on the test, between 28 and $74 \%$ of 12.4-year-old American Indian youths are in the healthy fitness zone. The majority of participants failed to meet healthy fitness zone for muscular strength and estimated body composition. Overall, $7 \%$ of the students were in the healthy fitness zone for all five components and 6\% failed to reach the healthy fitness zone for any of the tests (Brusseau, Finkelstein, Kulinna, \& Pangazi, 2014). In the study by Garber, Sajuria, and Lobelo (2014), $26 \%$ of boys and $55 \%$ of girls had unhealthy cardiorespiratory fitness, $29 \%$ of boys and $35 \%$ of girls had unhealthy musculoskeletal fitness, $29 \%$ of boys and $44 \%$ of girls had unhealthy BMI.

We observed that in NFPE attending group results of muscular fitness (except for upper body muscular strength and endurance) were higher than the country average values. BMI was higher than average values of sixth-graders in Lithuania. The results of muscular fitness of sixth-graders not attending NFPE were lower, and BMI, as in the group attending NFPE, were higher than the average values of sixth-graders in Lithuania. The cardiorespiratory fitness of all children groups (except for boys attending NFPE - below sufficient) according to Volbekiene and Kavaliauskas (2007) were estimated as insufficient.

Photiou et al. (2008) compared some selected morphological and functional parameters of 7-14-year-old Hungarian schoolboys living in the middle of the 1970s and at the beginning of the new millennium. Means of height, body mass, body mass index, the sum of five skinfold tests, percentage of body fat, and two running performance times $(400 \mathrm{~m}$ and $1.200 \mathrm{~m})$ of the boys $(n=3672)$ studied in 1975 were compared to those of the boys $(n=3758)$ in 2005. Scientists observed significant secular changes in body mass and height. In addition, boys in 2005 had significantly more subcutaneous fat compared to 1975 . The running times for the two distances were significantly poorer at the time of the second investigation. Similar trends were found for the Lithuanian children's physical fitness. Volbekienè and Kavaliauskas (2002) found, that during 10 years (1992-2002) for both genders sixth grade pupils' flexibility and cardiorespiratory fitness as well as girls' standing long jump and boys' upper body strength and endurance indices got worse statistically significantly. Comparing our research results with Lithuanian sixth graders' physical fitness data in 2002, we determined very similar tendencies: pupils' upper body muscular strength and endurance deteriorate, though their BMI increases. Estimating the indices of participants' cardiorespiratory system endurance, with reference to Volbekienè and Kavaliauskas (2007), we can maintain that 1610 meters run/walk results of six-graders are at a low level. We recommend including more exercises for upper body strength and endurance and cardiorespiratory fitness into their physical education, and providing pupils with the knowledge about benefits of these exercises for health enhancement and strengthening. 
NFPE programs that include a physical activity component can be effective in improving physical activity levels and physical fitness. Results of this study suggest that cardiorespiratory fitness and musculoskeletal fitness for boys who participated in NFPE were statistically significantly $(p<.05)$ higher than those in the group of non-attending NFPE. Similar results were found by London and Gurantz (2013). The scientists estimated that participation in fitness-focused NFPE programs was associated with a $10 \%$ increase in the probability of being physically fit after 2 years. This finding held for nearly all subgroups, including students who were initially unfit. Participation in 2 years of the program was associated with a $14.7 \%$ increased likelihood of subsequent fitness compared to $8.8 \%$ for 1 year of participation.

However, our study has shown that results for girls who participated in NFPE were marginally better than those who did not participate in NFPE. Only one test - Sit ups in 30 seconds (abdominal muscle strength and endurance) indices statistically significantly differed, $p<.05$. Whereas most of the girls attended dance classes, the assumptions that dance classes did not have significant impact on girls' cardiorespiratory and musculoskeletal fitness can be done.
Arriscado, Muros, Zabata, and Dalmau (2014) found that the male students who performed at NFPE and those at earlier stages of development reported higher levels of physical activity. The direct correlations between physical exercise and fitness were detected, especially with respect to aerobic capacity $(r=.38)$, and inverse correlations with hours in front of a screen $(r=-.18)$, but not with body composition. The NFPE influence on BMI also was not determined in our research.

Future research should examine the types of activities, duration of physical activity, and extent of participation for girls in NFPE programs aiming to better understand the link between NFPE programs and girls' physical fitness.

\section{CONCLUSION}

More attention must be paid to training sixth grade pupils' upper body muscular strength and endurance as well as cardiorespiratory fitness. Non-formal physical education is a meaningful educational form for increasing children's, particularly boys', health related physical fitness, therefore it is purposeful to encourage children to participate in physical activities in school and after classes.

\section{REFERENCES}

Ara, I., Vicente-Rodriguez, G., Perez-Gomez, J., Jimenez-Ramirez, J., Serrano-Sanchez, J. A., Dorado, C., \& Calbet, J. A. (2006). Influence of extracurricular sport activities on body composition and physical fitness in boys: A 3-year longitudinal study. International Journal of Obesity, 30(7), 1062-1071.

Arriscado, D., Muros, J. J., Zabata, M., \& Dalmau, J. M. (2014). Physical activity habits in schoolchildren: influential factors and relationships with physical fitness. Nutrición Hospitalaria, 31(3), 1232-1239. doi: 10.3305/nh.2015.31.3.8186

Beets, M. W., Beighle, A., Erwin, H. E., \& Huberty, J. L. (2009) After-school program impact on physical activity and fitness: A meta-analysis. American Journal of Preventive Medicine, 36(6), 527-537. doi: 10.1016/j. amepre.2009.01.033

BHFNC. (2010). Health Survey for England 2008: Focus on physical activity and fitness. Retrieved from http://www.be-activeltd.co.uk/assets/BHFNCSummary-Feb-2010.pdf.

Brusseau, T., A., Finkelstein, T., Kulinna, P. H., \& Pangazi, C. (2014). health-related fitness of American
Indian youth. Research Quarterly for Exercise and Sport, 85, 257-216.

California Department of Education. (2009). California After School Physical Activity Guidelines. Retrieved from http://www.cde.ca.gov/ls/ba/as/documents/paguidelines.pdf Carpio-Rivera, E., Moncada-Jiménez, J, SalazarRojas, W., \& Solera-Herrera, A. (2016). Acute Effects of Exercise on Blood Pressure: A Meta-Analytic Investigation. Arquivos Brasileiros de Cardiologia, May 6. Retrieved from http://www.ncbi.nlm.nih.gov/ pubmed/27168471

Carrel, A. L., Logue, J., Deininger, H., Clark, R. R., Curtis, V., Montague, P., \& Baldwin, S. (2011). An afterschool exercise program improves fitness, and body composition in elementary school children. Journal of Physical Education and Sports Management, 2(3), 32-36.

Chen, Y., Zheng, Z., Yi, J., \& Yao, S. (2014). Associations between physical inactivity and sedentary behaviors among adolescents in 10 cities in China. BMC Public Health, 14(1), 744. doi: 10.1186/1471-2458-14-744.

Costanian, C., Bennett, K., Hwalla, N., Assaad, S., \& Sibai, A. M. (2014). Prevalence, correlates and 
management of type 2 diabetes mellitus in Lebanon: Findings from a national population-based study. Diabetes Research and Clinical Practice, 105(3), 408-415. doi: 10.1016/j.diabres.2014.06.005

Currie, C. Cara Zanotti, Antony Morgan, Dorothy Currie, Margaretha de Looze, Chris Roberts, Oddrun Samdal, Otto R. F. Smith and Vivian Barnekow (Eds.) (2012). Social determinants of health and well-being among young people. HBSC study: international report from the 2009/2010 survey. WHO Regional Office for Europe.

De Baere, S., Philippaerts, R., De Martelaer, K., \& Lefevre, J. (2016). Associations between Objectively Assessed Components of Physical Activity and HealthRelated Fitness in 10- to 14-Year-Old Children. Journal of Physical Activity \& Health, May 11. Retrieved from http://www.ncbi.nlm.nih.gov/pubmed/27169461

Drake, K. M, Beach, M. L., Longacre, M. R., Mackenzie, T., Titus, L. J., Rundle A. G., \& Dalton, M. A. (2012). Influence of sports, physical education, and active commuting to school on adolescent weight status. Pediatrics, 130(2), 296-304.

Gallahue, D. L., \& Ozmun, J. C. (2006). Understanding motor development: Infants, children, adolescents, adults. Boston, Mass: McGraw-Hill.

Garber, M. D., Sajuria, M., \& Lobelo, F. (2014). Geographical variation in health-related physical fitness and body composition among Chilean 8th graders: A Nationally representative cross-sectional study. PLoS ONE 9(9), e108053. doi:10.1371/journal.pone.0108053.

Gortmaker, S. L., Lee, R. M., Mozaffarian, R. S., Sobol, A. M., Nelson, T. F., Roth, B. A., \& Wiecha, J. L. (2012). Effect of an after-school intervention on increases in children's physical activity. Medicine and Science in Sports and Exercise, 44(3), 450-457.

Heshmat, R., Qorbani, M., Shahr Babaki, A. E., Djalalinia, S., Ataei-Jafari, A., Motlagh, M. E., ... Kelishadi, R. (2016). Joint association of screen time and physical activity with cardiometabolic risk factors in a national sample of Iranian adolescents: The CASPIANIII study. Public Library of Science, 11(5), e0154502. doi: 10.1371/journal.pone.0154502

Heyward, V. H. (2010). Advanced fitness assessment and exercise prescription. Champain, IL: Human Kinetics.

Hilmn, C. H., Erikon, K. I., \& Kramer, A. F. (2008). Be smart, exercise your heart: exercise effects on brain and cognition. Nature Reviews. Neuroscience, 9(1), 58-65.

Kenney, W. L., Wilmore, J. H., \& Cosill, D. L. (2012). Physiology of sport and exercise. Champaign, IL: Human Kinetics.

Kromerova, E., \& Šukys, S. (2016). Adolescent involvement in sports activities and internalisation of moral values. Baltic Journal of Sport and Health Sciences, 1(100), 22-30.
London, R.A., \& Gurantz, O.(2013).Afterschool program participation, youth physical fitness, and overweight. American Journal of Preventive Medicine, 44(Suppl. 3), 200-207. doi: 10.1016/j.amepre.2012.11.009

Lubans, D., \& Morgan, P. (2008). Evaluation of an extracurricular school sport programme promoting lifestyle and lifetime activity for adolescents. Journal of Sports Sciences, 26(5), 519-529.

Malacko J., \& Pejčić A. (2009). Changes in biomotor dimensions of school boys aged 11: Experimental programme of sports games VS standard PE programme. Sport Science, 1, 52-61.

Nguyen-Michel, S. T., Unger, J. B., Hamilton, J., \& Spruijt-Metz, D. (2006). Associations between physical activity and perceived stress/hassles in college students. Stress and Health, 22, 179-188.

Olds, T., Wake, M., Patton, G., Ridley, K., Waters, E., Williams, J., \& Hesketh, K. (2008). How do schoolday activity patterns differ with age and gender across adolescence? Journal of Adolescent Health, 44(1), 64-72. doi: 10.1016/j.jadohealth.2008.05.003

Photiuo, A., Anning, J. H., Mẻsźaros, J. Vaida, I., Mẻsźaros, Z., Sziva, A,...Ng, N. (2008). Lifestyle, body composition, and physical fitness changes in Hungarian school boys (1975-2005). Research Quarterly for Exercise and Sport, 79, 166-173.

Rottensteiner, M., Leskinen, T., Niskanen, E., Aaltonen, S., Mutikainen, S., Wikgren, J.,... Kujala, U. M. (2014). Physical activity, fitness, glucose homeostasis, and brain morphology in twins. Medicine and Science in Sports and Exercise, 47(3), 509-518. doi: 10.1249/MSS.0000000000000437

Schneider, M., Dunn, A., Cooper, D. (2009). Affect, exercise, and physical activity among healthy adolescents. Journal of Sport \& Exercise Psychology, 31, 706-723.

da Silva, L. S, Fisberg, M., de Sousa Pires, M. M, Nassar, S. M., \& Sottovia, C. B. (2013). The effectiveness of a physical activity and nutrition education program in the prevention of overweight in schoolchildren in Criciúma, Brazil. European Journal of Clinical Nutrition, 67(11), 1200-1204.

Sioen, I., Michels, N., Polfliet, C., De Smet, S., D’Haese, S, Roggen, I, Deschepper, J, ...De Henauw, S. (2015). The influence of dairy consumption, sedentary behaviour and physical activity on bone mass in Flemish children: a cross-sectional study. BMC Public Health, Jul 28. doi: 10.1186/s12889-015-2077-7.

Skernevičius, J., Milašius, K., Raslanas, A., \& Dadelienè, R. (2011). Sporto treniruote. Vilnius: VPU.

Sports Council for Wales. (2009). Young People's Participation in Sport. Retrieved from http://sport. wales/media/346127/update_65(62)_e.pdf 
Tudor-Locke, C., Lee, S. M., Morgan, C. F., Beighle, A., \& Pangazi, R. P. (2006). Children's pedometerdetermined physical activity during the segmented school day. Medicine and Science in Sports and Exercise, 38(10), 1732-1738.

Volbekienè, V., \& Kavaliauskas, S. (Eds.). (2002). Eurofitas. Fizinio pajègumo testai, metodika. Lietuvos moksleiviu fizinio pajegumo rezultatai. Vilnius: LSIC.

Volbekienè, V., \& Kavaliauskas, S. (2007). Žinios mokiniui - fizinis pajègumas ir jo stiprinimas. [Knowledge for a student - physical capacity and its strengthening]. In A. Muliarčikas, Lietuvos gyventoju fizinio pajègumo testavimo ir fizinès būklès nustatymo metodika (pp. 16-21). Vilnius: LSIC.
Wang, C., Bannuru, R., Ramel, J., Kupelnick, B., Scott, T., \& Schmid, C. H. (2010). Tai Chi on psychological well-being: Systematic review and metaanalysis. BMC Complement Alternative Medicine, 10(1), 23. doi: 10.1186/1472-6882-10-23

Мирошниченко, Л. И., \& Астраханцев, Е. А. (2005). Инновационная программа физического воспитания школьников. Физическая культура: воспитание, образование, тренировка, 4, 60-64.

Синявский, Н. И., Власов, В. В., \& Сергеев, К. В. (2009). Мониторинг физической подготовленности детей младшего школьного возраста Среднего Приобья. Физическая культура: воспитание, образование, тренировка, 3, 31-32.
Corresponding author Asta Šarkauskienè Department of Physical Education Klaipėda University

H. Manto str. 84, LT-92294 Klaipeda Lithuania

Email asta.sarkauskiene@ku.lt 